\title{
Coffee crop weeds: refuge and food source for pests' natural enemies
}

\author{
Arvenses del cultivo de café: refugio y fuente de alimentos para los \\ enemigos naturales de las plagas
}

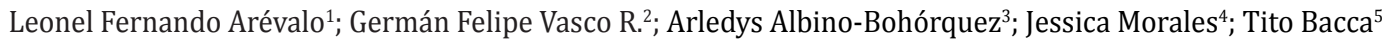

\begin{abstract}
ARTICLE DATA
Researcher, Agronomist Engineer, Grupo de Investigación en Moscas de las Frutas "GIMFRUT", Universidad del Tolima, Colombia, Ifarevaloa@ gmail.com

2 Researcher, Agronomist Engineer, Grupo de Investigación en Moscas de las Frutas "GIMFRUT", Universidad del Tolima, Colombia, felipevascor25@gmail.com

3 Biologist, Grupo de Investigación en Moscas de las Frutas "GIMFRUT", Universidad del Tolima, Colombia. arledysab@gmail.com

4 Biologist, M.Sc. Corporación Universitaria Minuto de Dios - UNIMINUT0, Bogotá, D. C., Colombia, jessica.morales@uniminuto.edu.co

5 Titular Professor, Ph.D. Universidad del Tolima, Colombia, titobacca@ut.edu.co
\end{abstract}

Cite: Arevalo, L.; Vasco, G.; Albino-Bohórquez, A.; Morales, J.; Bacca, T. (2021). Coffee crop weeds: refuge and food source for pests' natural enemies. Revista de Ciencias Agrícolas. 38(2): 36-49.

doi: https://doi.org/10.22267/rcia.213802.157.

Received: May 182021.

Accepted: July 272021.

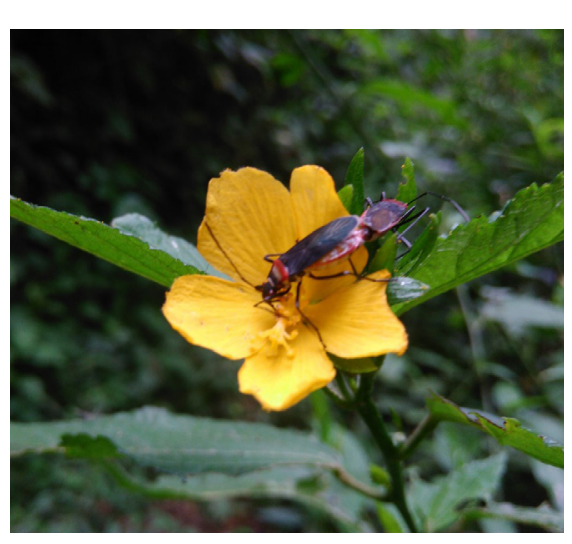

\section{ABSTRACT}

Weeds in coffee crops have diverse ecosystem services, such as sheltering and feeding natural enemies of pest insects. This study aimed to identify the potential of coffee weeds as food and refuge for natural enemies in shaded and sun coffee crops. Weeds were sampled in a $100 \mathrm{~m}$ transect installed in each type of coffee crop. Malaise traps and sweep-nets were both used to capture insects every 15 days for five months. After identifying the dominant weeds, observations and a direct recollection of insects were carried out at three different hours during three days. Faunistic analyses were performed, as well as the Bray and Curtis similarity analysis and the Student's t test. Emilia sonchifolia, Acmella oppositifolia, Bidens pilosa were predominant in the free exposure sun plantation coffee crops and Commelina diffusa, Salvia palifolia, Stachytarpheta cayennensis in under shade coffee crops. High insect activity was found between 11:30 am12:00 pm. In these weeds, we found about 15 families, the most important were Formicidae, Braconidae, and Coccinellidae. We concluded that the shaded coffee crops exhibited a natural enemy community similar to that of the sun. Through this exploratory study, we verified that weeds harbor a diversity of natural enemies important to the coffee agroecosystems.

Keywords: Coffee agroecosystem; biological control by conservation; shaded coffee; sun coffee; natural control; activity hours.

\section{RESUMEN}

Las arvenses en el cultivo de café tienen diversos servicios ecosistémicos, uno de ellos es servir de refugio y alimento de enemigos naturales de insectos plaga. El objetivo de este estudio fue identificar el potencial de las arvenses del café como alimento y refugio de enemigos naturales en el café de sombra y sol. Se realizó muestreos de arvenses en un transecto de $100 \mathrm{~m}$, en cada tipo de cafetal. Para la captura de insectos se utilizó al mismo tiempo, trampas Malaise y capturas manuales cada 15 días durante cinco meses. Luego de identificar las arvenses dominantes, se 
llevaron a cabo observaciones y una recolección directa de insectos a tres horarios diferentes, durante tres días. Se realizaron análisis faunísticos, así como el análisis de similitud de Bray Curtis y la prueba T de Student. Las arvenses predominantes en cafetal de sol y sombra fueron Emilia sonchifolia, Acmella oppositifolia, Bidens pilosa y Commelina diffusa, Salvia palifolia, Stachytarpheta cayennensis respectivamente, en las cuales se encontraron mayor actividad de insectos en el horario de 11:30-12:00 pm. En estas arvenses se encontraron hasta 15 familias donde se destaca las familias; Formicidae, Braconidae y Coccinellidae. El sistema bajo sombrío presentó una fauna de enemigos naturales similar con respecto al cafetal a libre exposición. Mediante este estudio exploratorio comprobó que las arvenses albergan una diversidad de enemigos naturales importante en los agroecosistemas cafeteros.

Palabras clave: Agroecosistema cafetero; control biológico por conservación; café de sombra; café al sol; control natural; horario de actividad.

\section{INTRODUCTION}

Coffee (Coffea arabica), native to Africa, has been spread to more than 100 countries in the tropics and subtropics. More than 3,000 species of insects and mites are registered and associated with this plant (Waller et al., 2007). Traditional coffee crops are cultivated under shade trees, generating a complex and floristically diverse structure that increases the availability of habitats and alternative food resources that serve as sustenance for a high diversity of species that include phytophages, parasitoids, and predators among others (Perfect et al., 1996; Waller et al., 2007; Vandermeer et al., 2010). In contrast to coffee plantations at full exposure, when converted into homogeneous monocultures to improve farmer's profitability by increasing production and yields in the short term. (Perfecto et al., 1996; Perfecto et al., 2005; Armbrecht and Gallego, 2007; Ramírez et al., 2013).

In biological control, man is in charge of helping and manipulating the natural enemies to be more efficient. This can be achieved through various approaches: classical biological control, biological control by augmentation, and biological control by conservation (Van-Driesche et al., 2008). Biological control by conservation is based on avoiding and counteracting habitat loss and environmental disturbances generated by intensive production crops to conserve natural enemies that contribute to pest reduction (Begg et al. 2017). Up to now, Conservation Biological Control strategies have focused on providing ideal habitat and food conditions for natural enemies (Begg et al. 2017). These include reducing the disturbance associated with extensive use of pesticides, tillage, and other farming operations, as well as establishing beneficial habitats to offset the overall reduction in habitat quality and diversity in the agricultural landscape (Begg et al. 2017).

Coffee crops can host up to 850 phytophagous species (Le Pelley, 1973). However, Bustillo (2008) ensures that these species have a good number of natural enemies that control their populations and reduce them to levels that do not cause economic damage. One of the strategies that allows to conserve these natural enemies is weed conservation, which increases possibilities of finding optional preys, shelters, places for reproduction, dormancy sites, and sources of nectar as an alternative food (Lundgren, 2009).

Several studies on coffee crops have been carried out, mainly in Mexico and Colombia. These have aimed to evaluate the function of some natural enemies and their potential to be biological 
controllers and have also explored the possibility of applying biological control by conservation. Most of these studies are based on trees as the main alternative food source to natural enemies, (Perfecto et al., 1996; Armbrecht and Gallego, 2007; Bustillo, 2008; Vandermeer et al., 2010; Morris et al., 2018; Jimenez-Soto et al., 2019). However, very few studies report the advantages of weeds as a source of nectar, pollen, and refuge for beneficial insects (Aldana et al., 1997; Blanco and Leyva, 2013).

Therefore, this work aimed to identify the weeds with the potential to feed and shelter natural enemies in shaded and sun coffee crops. It also aimed to determine the diversity of families of natural enemies associated with the weeds and their peak hours of activity.

\section{MATERIAL AND METHODS}

Location. The study was carried out at the "La Luisa" farm in Cataimita village, municipality of Ibagué, Tolima department $\left(4^{\circ} 25.838^{\prime} \mathrm{N}\right.$ and $75^{\circ} 18.760^{\prime} \mathrm{W}$ ). The region has an average temperature of $24^{\circ} \mathrm{C}$, a bimodal rain regime (two specific seasons, April-May and OctoberNovember), an average rainfall of $1,691 \mathrm{~mm} /$ year (Peláez and Santamaría, 2010), and an average altitude of $1.512 \mathrm{~m}$. According to Gómez et al. (1991), it is located in the coffee crops ecotope 209B.

Two Castillo variety coffee crops were evaluated: one shaded and the other at sun, each one with an area of approximately $2500 \mathrm{~m}^{2}$. The coffee crops were not separated by any type of physical barrier; plants spacing was 1.5 x $1.6 \mathrm{~m}$ between plants and rows respectively. The plants were four years old. The two crops had conventional management, using edaphic fertilization every three months. The phytosanitary management consisted in harvesting the fruits in the coffee crops to promptly avoid the proliferation of coffee berry borer. During a semester, weed trimmer was suspended to allow weed growth. The shaded crop had 40 companion trees: Citrus sinensis, Annona muricata, Musa sp, and Persea americana 10, 6, 2, and 15 years old respectively.

Assessment of weeds associated with shaded and sun coffee. Weeds were randomly sampled with a $1 \mathrm{~m}^{2}$ wooden frame, in a $100 \mathrm{~m}$ transect. The sample was replicated 15 times in each coffee crop system. Within each sample, the weeds were collected and carried to the botanical press. The plants with reproductive structures were inspected to determine the occurrence of insect food sources or shelter. The collected material was identified using the book "Manejo y control integrado de malezas en cafetales y potreros de la zona cafetera" (Gómez et al., 1987), and later verified with the "Herbarium Toli" of the University of Tolima.

Activity of insects associated with weeds identification. Observations and a direct collection of insects were made using an insect net in the weed characterized. To determine the time of higher activity of the insects, three samplings were carried out in the morning (9:00-9:30 am), afternoon (11:30-12:00 m.), and night (7:00-7:30 pm) over three days $(\mathrm{N}=376)$. The collection of insects was carried out in transects of 20 meters, in the areas of the coffee crop where there was a greater incidence of the selected weeds, by swinging the insect net fifteen times in each direction. Once the insects were collected, they were identified to determine which insect families had the potential to be biological controllers.

Sampling of insects associated with shaded and sun coffee. Two collecting methods for sampling insects were used at the same time: Malaise traps and hand netting. One trap was 
installed in each coffee crop and was evaluated every 15 days for five months (July to November 2017). The handled insect net was swept over the selected weeds, using three transects by type of coffee crop every 15 days for five months (July - November 2017).

During the evaluation period, climatic conditions were characterized by an average daily relative humidity of $78.55 \%$, with daily maximum temperatures of $31^{\circ} \mathrm{C}$ and minimum temperatures of $19^{\circ} \mathrm{C}$. The average precipitation on the sampling days was $8.29 \mathrm{~mm} /$ pluviometric day, with rainfall peaks during October (222.1 total $\mathrm{mm}$ ) and November ( 314.5 total $\mathrm{mm}$ ) and dry season in July (24.4 total $\mathrm{mm}$ ). (Instituto de Hidrología, Meteorología y Estudios Ambientales - IDEAM, 2021).

The captured insects were kept in screw capsealed plastic bottles $(80 \mathrm{ml})$ with $70 \%$ alcohol and then taken to the Entomology Laboratory of the University of Tolima. The identification of these specimens was done with the taxonomic keys of Triplehorn and Johnson (2005) and Rafael et al. (2012).

Faunistic index and statistical analysis. To compare the weeds and insects with the two capture methods (hand netting and Malaise trap) in the shaded and sun coffee, the faunistic indices proposed by Silveira Neto et al. (1976) and Southwood (1995) were used.

Diversity index: Margalef diversity index $(\alpha)$ (Silveira Neto et al., 1976) refers to the diversity of species within a community or habitat. It represents the niche utilization pattern, provided that a community with few species have many individuals and many species have few individuals.
$S_{T}=\alpha \ln \left(1+\frac{N}{\alpha}\right)$

Where:

$\mathrm{S}_{\mathrm{T}}=$ Total species present in the area

$\mathrm{N}=$ Total number of specimens collected in the area

$\alpha=$ Diversity Index

Based on the previous equation, the Diversity Index is found as follows:

$$
\alpha=\frac{S_{T}-1}{\ln N}
$$

Frequency: percentage of individuals of a species with the total number of individuals collected.

$F=\frac{I}{T} \times 100$

Where:

$\mathrm{I}=$ number of individuals of a species in the area

$\mathrm{T}=$ Total number of individuals collected in the area

Constancy: refers to the percentage of sample units on which a species was present. The species can be: constant, present in more than $50 \%$ of the sample units; accessory, present in $25 \%$ to $50 \%$ of the sample units, and accidental, present in less than $25 \%$ of the sample units.

$C=\frac{p \times 100}{N}$

Where:

$\mathrm{p}=$ number of samples containing insects

$\mathrm{N}=$ Total number of samples made.

Abundance: number of individuals per unit area or volume, with a variation on space and time. To estimate it, the confidence intervals are calculated at the $1 \%$ and $5 \%$ levels. 
$I C=m \pm t \times s(m)$

In which:

$$
m=\frac{\sum x}{n} \quad S(m)=\frac{S}{\sqrt{n}} \quad S^{2}=\frac{\sum X^{2}-\frac{(\Sigma x)^{2}}{n}}{n-1}
$$

Where:

$$
\begin{aligned}
\mathrm{CI}= & \text { Confidence interval } \\
\mathrm{t}= & \text { value of } \mathrm{t} \text { at the level of } 5 \% \text { and } \\
& 1 \% \text { with } \mathrm{n}-1 \mathrm{G} . \mathrm{L} \\
\mathrm{m}= & \text { Average number of individuals captured } \\
& \text { in the area } \\
\mathrm{S}= & \text { Variance } \\
\mathrm{X}= & \text { total individuals of each species in the } \\
& \quad \text { area } \\
\mathrm{n}= & \text { number of species in the area }
\end{aligned}
$$

The following abundance classes are thus established (li = lower limit and ls = upper limit of the confidence interval. R: rare, d: scattered, c: common, a: abundant, m: very abundant).

Dominance: $\mathrm{LD}=1 / \mathrm{S} \times 100$, where $\mathrm{D}=$ dominance limit $(\%)$, $\mathrm{S}=$ total number of species of the sample.

$$
D=\frac{1}{S} \times 100
$$

Where:

$S=$ total number of species in the area.

Similarity analysis. The Bray and Curtis (1957) index is used to quantify the compositional dissimilarity between two different sites, based on counts at each site. The Bray and Curtis index is calculated with the following formula:

$S=$ total number of species in the area
Where:

$C_{i j}=$ the sum of the lower value for only those species in common between both sites

$S_{i}$ y $S_{j}=$ the total number of specimens counted at both sites.

The index is reduced to $2 \mathrm{C} / 2=\mathrm{C}$, where the abundance at each site is expressed as a percentage. The dissimilarity of Bray-Curtis (1957) is bounded between 0 and 1, where 1 means that the two sites have the same composition (that is, they share all species), and 0 means that the two sites do not share any species. The analysis was carried out using the Past 2.17 program.

In addition, a comparison of the two systems was performed using the Student's t-test.

\section{RESULTS AND DISCUSSION}

\section{Samples of weeds associated with shaded} and sun coffee. In the sun coffee crop, a total of 489 individuals were registered, belonging to 20 species and 9 families. The families with the highest representation were Asteraceae and Poaceae with 63\% and 11\% respectively; Malvaceae, Rubiaceae, Cyperaceae, Commelinaceae, Amarantaceae, Verbenaceae, and Piperaceae were also registered, with a lower presence (Table 1). In the shaded coffee, a total of 425 individuals, belonging to 16 species, and 9 families were recorded; Asteraceae, Verbenaceae, Commelinaceae, and Lamiaceae predominated, with 25, 23, 20, and 16\%, respectively (Table 1). The Poaceae, Rubiaceae, Cyperaceae, Euphorbiaceae, and Oxalidaceae families were also recorded. 
Tabla 1. Comparison of frequency, density, and constancy of the most representative species of weeds of shaded and sun coffee.

\begin{tabular}{|c|c|c|c|c|c|c|c|c|c|}
\hline \multirow{3}{*}{ Specie } & \multirow{3}{*}{ Family } & \multicolumn{4}{|c|}{ sun coffee } & \multicolumn{4}{|c|}{ shaded coffee } \\
\hline & & \multirow{2}{*}{$\mathbf{T}$} & F\% & Den & \multirow{2}{*}{$\mathbf{C}$} & \multirow{2}{*}{$\mathbf{T}$} & F \% & Den & \multirow{2}{*}{ C } \\
\hline & & & \multicolumn{2}{|c|}{ ind $/ \mathrm{m}^{2}$} & & & \multicolumn{2}{|c|}{ ind $/ \mathrm{m}^{2}$} & \\
\hline Acmella oppositifolia (Lam.) R.K.Jansen & Asteraceae & 71 & 14.5 & 4.73 & 40 & 0 & 0 & 0 & 0 \\
\hline Bidens pilosa L. & Asteraceae & 69 & 14.1 & 4.6 & 40 & 0 & 0 & 0 & 0 \\
\hline Commelina diffusa Burm.f. & Commelinaceae & 20 & 4.09 & 1.3 & 20 & 78 & 18.3 & 5.2 & 20 \\
\hline Emilia sonchifolia (L.) DC. ex DC. & Asteraceae & 89 & 18.2 & 5.9 & 60 & 13 & 3.05 & 0.86 & 6.67 \\
\hline Salvia palifolia Kunth & Lamiaceae & 0 & 0 & 0 & 0 & 62 & 14.5 & 4.13 & 53.3 \\
\hline Stachytarpheta cayennensis (L. C. Rich.) & Verbenaceae & 25 & 5.11 & 1.6 & 20 & 92 & 21.6 & 6.13 & 46.7 \\
\hline
\end{tabular}

$\mathrm{T}=$ Total specimens collected, $\mathrm{F}=$ Frequency, Den $=$ Density, $\mathrm{C}=$ Constancy.

Although shade systems increase the biodiversity of insects, they also generate a lower presence of weeds, offering greater efficiency in hand weeding and benefits to the soil (Staver et al., 2020). This coincides with our obtained observation that fewer weeds were present in the shaded coffee compared to the sun coffee. In both systems, the dominant weeds belong to the Asteraceae family. In addition to being the most relevant host for entomophagous, this family is also important for beekeeping; the nectar of its flowers is the favorite of some flies of the Tachinidae family (Vázquez et al., 2008; Gómez et al. 1987). In shaded coffee, in addition to the Asteraceae family, the Verbenaceae, Commelinaceae, and Lamiaceae families also stand out. According to Aldana et al., (1997), the Verbenaceae and Lamiaceae families are hosts of several parasitoids in oil palm crops.

In the case of sun coffee, Emilia sonchifolia (Asteraceae), Acmella oppositifolia (Asteraceae) and Bidens pilosa (Asteraceae) were more frequent. These weeds are characterized by having a high reproductive capacity per seed (more than 4000 per plant), being invasive, and having resistance to dry periods in coffee crops, which makes it difficult to manage (Gómez et al. 1987). In addition, these plants can be harmful to coffee crops because they attract the coffee berry borer (Castro et al., 2017). However, E. sonchifolia can be a food source for biological controllers, such as the parasitoids Brachymeria sp and Rhysipolis sp, which are natural enemies of oil palm defoliators (Sendoya-Corrales and Bustillo, 2016). Acmella oppositifolia is important in the conservation of the parasitoid Jaynesleskia jaynesi (Tachinidae fly), natural enemy of larvae of the sugarcane borer (Diatraea spp.) (Vargas et al., 2006).

The weeds Stachytarpheta cayennensis (Verbenaceae), Commelina diffusa (Commelinaceae), and Salvia palifolia (Lamiaceae), predominant in shaded coffee crops, can be important sources of food due to their variety of attributes such as a long period of profuse flowers and vibrant colors, volumes of nectar and considerable pollen grains, adequate growth for soil protection, and unusual morphologies to attract a variety of pollinators (Barp etal., 2010; De La Vega et al., 2000; Lundgren, 2009; Reith and Zona 2016). 
Hours of higher activity of insects associated with weeds identification. The total number of insects collected in the three days was 376 , identified in two classes and 6 orders. The time of higher activity and abundance of the insects was between 11:30 am and 12:00 pm, with a total of 168 individuals, equivalent to $44 \%$ of the specimens collected. The orders Hemiptera, Diptera, Coleoptera, and Hymenoptera were predominant. The second time of higher activity was in the morning (120 individuals) and night (88 individuals) with a presence predominant of Hemiptera and Diptera orders (Figure 1).

Comparative and experimental studies support the opinion that high temperatures improve organism performance since they inevitably accelerate chemical reactions. However, the thermodynamic effect on maximum performance varies greatly between traits and taxa (Angilletta et al., 2010). Insects are ectothermic organisms that are affected by numerous seasonal and diurnal changes in abiotic conditions (Chen et al., 2017), thus need to be exposed to the capture of energy to fulfill their vital functions.
Several studies affirm that the time in which there is a greater activity of insects is at noon. Fernández et al. (2001) determined that the best time to collect more biodiverse insects is from 9:00 to 9:30 and the second from 12:00 to $12: 30$, possibly due to a great availability of food at the beginning of anthesis in the flowers of the species studied. According to Carles-Tolrá (2015), some families of the Diptera order are more active during diurnal hours with higher temperatures, although a few are nocturnal.

Sampling of insects associated with shaded and sun coffee. The total number of individuals registered, with the Malaise trap during the five months, in sun coffee sampling was 160, belonging to 27 families, of which 15 represent possible natural enemies. The families Formicidae, Ichneumonidae, Braconidae, Chrysomelidae, Evaniidae, and Pompilidae, were dominant. Almost all families presented a common level of abundance, except for Formicidae, which had a very abundant category and a constancy of 90 (Table 2).

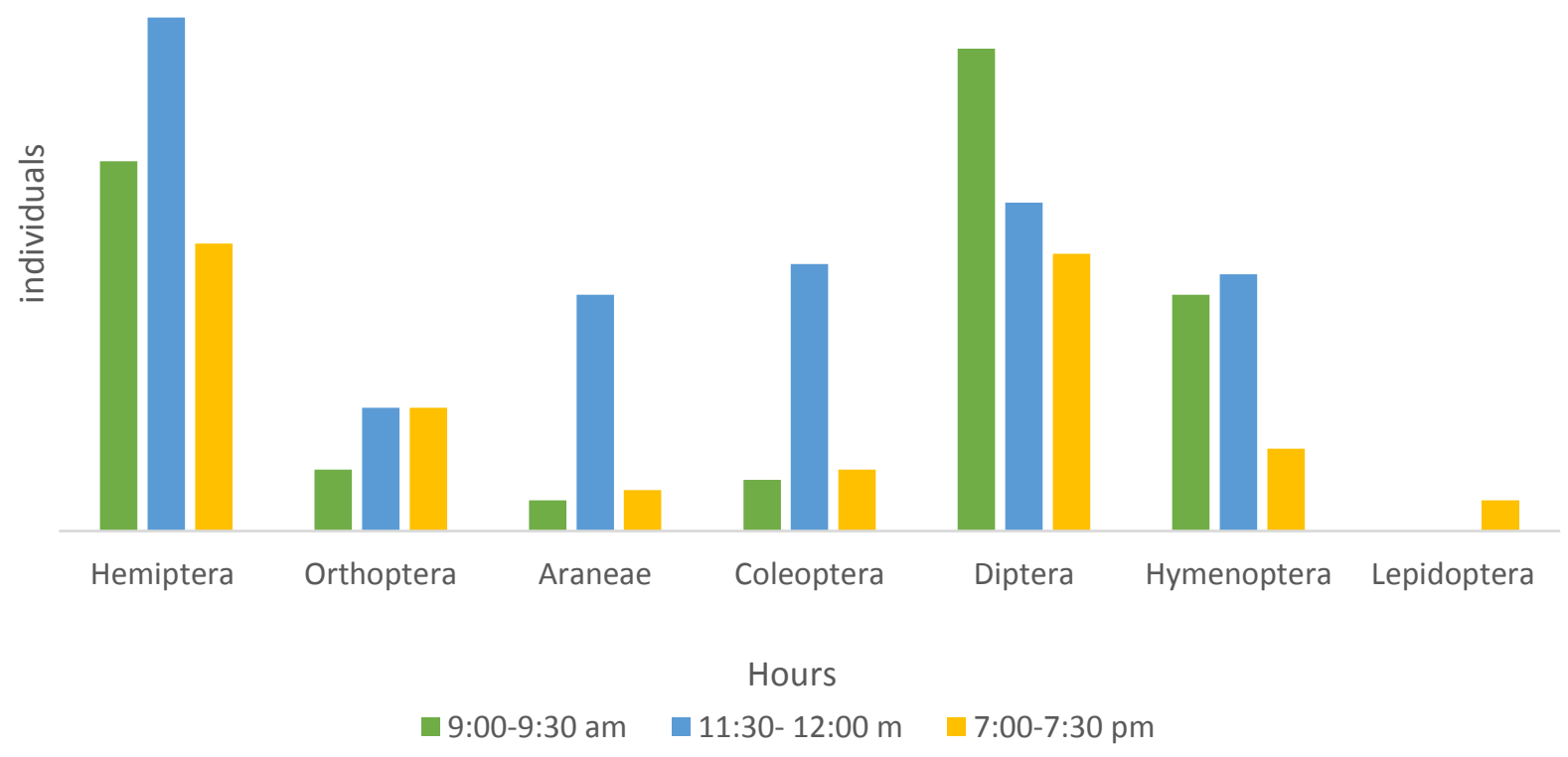

Figure 1. Total of arthropods at different times in weeds of the coffee crops. 
In the Malaise trap installed in the shaded coffee, a total of 168 individuals and 34 families were found, 22 of the possible natural enemies. The families Coccinellidae, Evaniidae, Formicidae, Ichneumonidae, Staphylinidae, Tachinidae, and Vespidae were dominant (Table 2).
The diversity index was higher in the shaded coffee (6.4) than in the sun coffee crop (5.2). In addition, the shaded coffee had the highest population and family variety. The two systems shared 19 of the 42 total families; of these, the Formicidae had the highest incidence (Table 2).

Table 2. Frequency, constancy, dominance, and index of abundance, of the insects captured with the Malaise trap present in the shaded and sun coffee

\begin{tabular}{|c|c|c|c|c|c|c|c|c|c|c|c|}
\hline \multirow{2}{*}{ Family } & \multicolumn{5}{|c|}{ sun coffee } & \multicolumn{5}{|c|}{ shaded coffee } & \multirow{2}{*}{$\mathbf{T}$} \\
\hline & $\mathbf{T}$ & $\mathbf{F}$ & $\mathrm{C}$ & D & $\mathbf{A}$ & $\mathbf{T}$ & $\mathbf{F}$ & C & D & $\mathbf{A}$ & \\
\hline Alleculidae & 1 & 0.63 & 10 & ND & $\mathrm{C}$ & 0 & 0 & 0 & - & - & 1 \\
\hline Apidae & 0 & 0 & 0 & - & - & 7 & 4.17 & 50 & D & $\mathrm{C}$ & 7 \\
\hline Asilidae & 0 & 0 & 0 & - & - & 1 & 0.60 & 10 & ND & $\mathrm{C}$ & 1 \\
\hline Braconidae & 11 & 6.88 & 50 & D & $\mathrm{C}$ & 3 & 1.79 & 30 & ND & $\mathrm{C}$ & 14 \\
\hline Cerambycidae & 1 & 0.63 & 10 & ND & $\mathrm{C}$ & 0 & 0 & 0 & - & - & 1 \\
\hline Chalcididae & 1 & 0.63 & 10 & ND & $\mathrm{C}$ & 1 & 0.60 & 10 & ND & $\mathrm{C}$ & 2 \\
\hline Chrysomelidae & 11 & 6.88 & 60 & D & $\mathrm{C}$ & 3 & 1.79 & 20 & ND & $\mathrm{C}$ & 14 \\
\hline Chrysopidae & 0 & 0 & 0 & - & - & 1 & 0.60 & 10 & ND & $\mathrm{C}$ & 1 \\
\hline Coccinelidae & 5 & 3.13 & 30 & ND & $\mathrm{C}$ & 7 & 4.17 & 30 & D & $\mathrm{C}$ & 12 \\
\hline Curculionidae & 3 & 1.88 & 20 & ND & $\mathrm{C}$ & 1 & 0.60 & 10 & ND & $\mathrm{C}$ & 4 \\
\hline Dolichopodidae & 2 & 1.25 & 20 & ND & $\mathrm{C}$ & 3 & 1.79 & 30 & ND & $\mathrm{C}$ & 5 \\
\hline Elateridae & 1 & 0.63 & 10 & ND & $\mathrm{C}$ & 0 & 0 & 0 & - & - & 1 \\
\hline Erotylidae & 0 & 0 & 0 & - & - & 2 & 1.19 & 20 & ND & $\mathrm{C}$ & 2 \\
\hline Evaniidae & 7 & 4.38 & 50 & D & $\mathrm{C}$ & 5 & 2.98 & 30 & D & $\mathrm{C}$ & 12 \\
\hline Figitidae & 0 & 0 & 0 & - & - & 1 & 0.60 & 10 & ND & $\mathrm{C}$ & 1 \\
\hline Formicidae & 48 & 30.00 & 90 & D & M & 45 & 26.79 & 100 & D & $\mathrm{M}$ & 93 \\
\hline Halictidae & 1 & 0.63 & 10 & ND & $\mathrm{C}$ & 4 & 2.38 & 40 & ND & $\mathrm{C}$ & 5 \\
\hline Histeridae & 0 & 0 & 0 & 0 & 0 & 1 & 0.60 & 10 & ND & $\mathrm{C}$ & 1 \\
\hline Ichneumonidae & 35 & 21.88 & 10 & $\mathrm{D}$ & $\mathrm{C}$ & 31 & 18.45 & 100 & D & $\mathrm{C}$ & 66 \\
\hline Lampyridae & 2 & 1.25 & 10 & ND & $\mathrm{C}$ & 1 & 0.60 & 10 & ND & $\mathrm{C}$ & 3 \\
\hline Lauxaniidae & 0 & 0 & 0 & - & - & 1 & 0.60 & 10 & ND & $\mathrm{C}$ & 1 \\
\hline Lonchaeidae & 1 & 0.63 & 10 & ND & $\mathrm{C}$ & 1 & 0.60 & 10 & ND & $\mathrm{C}$ & 2 \\
\hline Lygaeidae & 0 & 0 & 0 & - & - & 1 & 0.60 & 10 & ND & $\mathrm{C}$ & 1 \\
\hline Melolonthidae & 1 & 0.63 & 10 & ND & $\mathrm{C}$ & 0 & 0 & 0 & - & - & 1 \\
\hline Miridae & 0 & 0 & 0 & - & - & 1 & 0.60 & 10 & ND & $\mathrm{C}$ & 1 \\
\hline Neididae & 0 & 0 & 0 & - & - & 2 & 1.19 & 20 & ND & $\mathrm{C}$ & 2 \\
\hline Nitidulidae & 0 & 0 & 0 & - & - & 3 & 1.79 & 20 & ND & $\mathrm{C}$ & 3 \\
\hline Phoridae & 0 & 0 & 0 & - & - & 1 & 0.60 & 10 & ND & $\mathrm{C}$ & 1 \\
\hline
\end{tabular}


Continuation Table 2

\begin{tabular}{|c|c|c|c|c|c|c|c|c|c|c|c|}
\hline \multirow{2}{*}{ Family } & \multicolumn{5}{|c|}{ sun coffee } & \multicolumn{5}{|c|}{ shaded coffee } & \multirow{2}{*}{$\mathbf{T}$} \\
\hline & $\mathbf{T}$ & $\mathbf{F}$ & C & D & $\mathbf{A}$ & $\mathbf{T}$ & $\mathbf{F}$ & & & $\mathbf{A}$ & \\
\hline Pompilidae & 6 & 3.75 & 50 & $\mathrm{D}$ & $\mathrm{C}$ & 3 & 1.79 & 30 & ND & $\mathrm{C}$ & 9 \\
\hline Pteromalidae & 0 & 0 & 0 & - & - & 1 & 0.60 & 10 & ND & $\mathrm{C}$ & 1 \\
\hline Ptilodactylidae & 1 & 0.63 & 10 & ND & $\mathrm{C}$ & 0 & 0 & 0 & - & - & 1 \\
\hline Reduviidae & 1 & 0.63 & 10 & ND & $\mathrm{C}$ & 0 & 0 & 0 & - & - & 1 \\
\hline Richardidae & 0 & 0 & 0 & - & - & 1 & 0.60 & 10 & ND & $\mathrm{C}$ & 1 \\
\hline Scarabaeidae & 1 & 0.63 & 10 & ND & $\mathrm{C}$ & 0 & 0 & 0 & - & - & 1 \\
\hline Scoliidae & 0 & 0 & 0 & - & - & 1 & 0.60 & 10 & ND & $\mathrm{C}$ & 1 \\
\hline Staphylinidae & 2 & 1.25 & 10 & ND & $\mathrm{C}$ & 14 & 8.33 & 60 & D & $\mathrm{C}$ & 16 \\
\hline Stratiomyidae & 3 & 1.88 & 30 & ND & C & 3 & 1.79 & 30 & ND & $\mathrm{C}$ & 6 \\
\hline Syrphidae & 5 & 3.13 & 40 & ND & $\mathrm{C}$ & 1 & 0.60 & 10 & ND & $\mathrm{C}$ & 6 \\
\hline Tachinidae & 5 & 3.13 & 30 & ND & $\mathrm{C}$ & 8 & 4.76 & 70 & $\mathrm{D}$ & $\mathrm{C}$ & 13 \\
\hline Tephritidae & 1 & 0.63 & 10 & ND & $\mathrm{C}$ & 0 & 0 & 0 & - & - & 1 \\
\hline Tipulidae & 2 & 1.25 & 20 & ND & C & 2 & 1.19 & 10 & ND & $\mathrm{C}$ & 4 \\
\hline Vespidae & 2 & 1.25 & 20 & ND & $\mathrm{C}$ & 7 & 4.17 & 70 & D & $\mathrm{D}$ & 9 \\
\hline Total & 160 & 100.00 & & & & 168 & 100.0 & & & & 328 \\
\hline Diversity Index & & 5.1229 & & & & & & 103 & & & - \\
\hline
\end{tabular}

T: total of individuals; F: frequency; C: constancy; D: dominance or dominant;

ND: not dominant; A: abundance; c: common, m: very abundant.

According to the Bray - Curtis index, the similarity in the structure of the shaded and sun coffee was 74.7\%; hence, the fauna found in the two systems was similar. For this analysis, the trophic guild of each family of insects was not specified (Table 3)

Table 3. Bray-Curtis similarity index of insect families captured in shaded and sun coffee.

\begin{tabular}{lcc}
\hline Coffee system & $\begin{array}{c}\text { Bray-Curtis } \\
\text { index in } \\
\text { Sun coffee }\end{array}$ & $\begin{array}{c}\text { Bray-Curtis } \\
\text { index in } \\
\text { Shaded coffee }\end{array}$ \\
\hline Sun coffee & 1 & 0.747 \\
\hline Shaded coffee & 0.747 & 1 \\
\hline
\end{tabular}

When comparing the abundance in the two systems using the T-student test, it was found that it was equal for both, with an average of $3.809 \pm 1.4$ for the sun coffee crop and $4 \pm 1.2$ for the shade coffee crop $(p=0.92)$.

According to the faunistic results, the sun coffee presented a fauna very similar in the number of insect families (phytophagous, natural enemies, and other habits) in comparison with the shaded coffee. However, the shaded coffee presented a greater presence of beneficial insects (parasitoids and predators) with $64 \%$, compared to sun coffee crops which was $55 \%$. 
This agrees with Borkhataria et al. (2012), which identified several entomophagous arthropods of the orders Coleoptera, Diptera, Hemiptera, Hymenoptera, and Neuroptera in shaded coffee, in addition to insectivorous birds. This system helps to keep the number of possible pests at low levels in coffee crops (Bizumungu et al., 2019). Nevertheless, Bagny et al. (2019) affirm that while the shade increases the number of beneficial insects, it also increases the infestation of the coffee borer, since in their study the percentage of shade was positively correlated with the initial infestation of the borer.

Faunistic analysis of natural enemies in weeds. For the weeds Emilia sonchifolia, Acmella oppositifolia, and Bidens pilosa belonging to the Asteraceae family, it was estimated that they possibly serve as a shelter, food source, or home for 29 different families of insects associated with the coffee entomofauna in sun coffee, of which 11 corresponded to families of natural enemies (Van-Driesche et al. 2008) (Table 4.)

For these weeds, the families Formicidae (14 individuals), Miridae (14 individuals), Braconidae (13 individuals), and Pteromalidae(13 individuals) presented the highest number of individuals. For almost all weeds, the aforementioned families dominated, except for the Miridae family in the species E. sonchifolia (Table 4).

In the case of Commelina diffusa, Salvia palifolia, and Stachytarpheta cayennensis, belonging to the families Commelinaceae, Lamiaceae, and Verbenaceae, respectively, it was found that they can be sources of pollen, shelter and home to 25 families of insects corresponding to the population related to the agroforestry system, of which 14 are families of natural enemies (Table 4).
As reported by Van-Driesche et al. (2008), the most important insects for this study were Hymenopterans of the family Formicidae, Braconidae, Ichneumonidae, Chalcididae, and Vespidae; Coleoptera of the Coccinellidae family, also orders such as Neuroptera with Chrysopidae, Diptera with families such as Syrphidae, Cecidomyiidae, and Dolichopodidae, finally Hemiptera with Reduviidae and Miridae (it is important to clarify that this family can also be phytophagous) (Table 4). These insects were found in greater numbers in the shaded coffee. Some species of Coccinellidae such as Stethorus sp. and Scymnus sp., generally inhabit coffee crops and are natural enemies of the coffee pest Oligoyichus yothersi known as "red spider mite" (Giraldo et al., 2011).

Based on our observations, ants occur naturally in coffee landscapes, which opens possibilities towards biocontrol by conservation (Morris et al., 2018). Species such as Wasmannia auropunctata and Solenopsis picea, Solenopsis geminata, Dorymyrmex sp., Pheidole sp. and Mycocepurus smithii are efficient predators of the coffee borer (Morris and Perfecto, 2016; Vélez et al., 2006).

Brévault and Clouvel (2019) state that diversity at different trophic levels must be considered, since there may be a tritrophic relationship between these plants, phytophages, and natural enemies. Understanding these relationships would help to understand the role of these organisms in the agroecosystem. This same author mentions that there are few studies in this regard and proposes that through the help of new technologies such as high-throughput sequencing and metabarcoding, it would be possible to discover the role of these organisms in the ecosystem. Also, it would be possible to understand these relationships and make the use of biological control for conservation more efficient. 


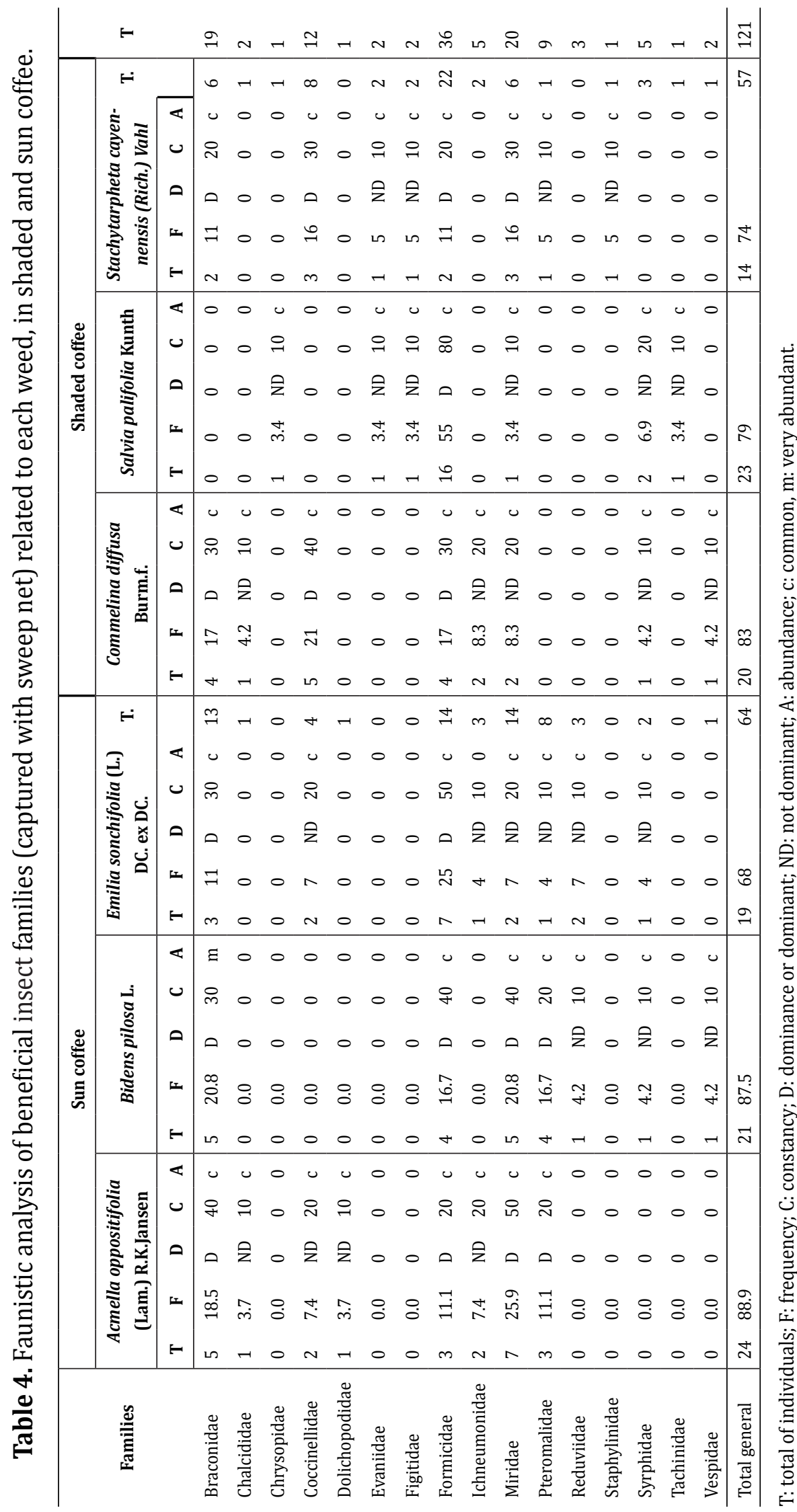


Using the manual capture method, this exploratory study recognized the importance of some weeds of the shaded coffee, such as Salvia palifolia, Stachytarpheta cayennensis and Commelina diffusa, and Emilia sonchifolia, Acmella oppositifolia in sun coffee (Table 4), which help maintain heterogeneity and structure in the ecosystem which favors the beneficial insects (Lundgren, 2009; Blanco and Leiva 2013).

Biological control by conservation should continue to be explored. This requires an ecological approach that identifies the characteristics at both the landscape and plant levels that are effective to support the population of natural enemies (Mkenda et al., 2020; Rusch et al., 2016). Local-scale connectivity between coffee crops and shady trees increases the complexity of the vegetation and contributes to the management of pests (Jimenez-Soto et al., 2019). Therefore, these weeds could also be playing a fundamental role in connectivity for beneficial insects.

\section{CONCLUSIONS}

The results obtained in this study allow us to conclude that both the shaded and sun coffee crops have a high diversity of weeds that serve as shelter and food for various natural enemies. In shaded coffee crops, the weeds Commelina diffusa, Salvia palifolia, and Stachytarpheta cayennensis stand out. They are associated with fifteen families of natural enemy insects; of these, the most representative are Formicidae, Coccinellidae, Braconidae, and Miridae. In sun coffee crops, the most important weeds identified were Acmella oppositifolia, Bidens pilosa, and Emilia sonchifolia, which host thirteen families of natural enemies, such as Formicidae, Miridae, Braconidae, and Pteromalidae.
During the days of sampling, the highest activity of natural enemies was between 11:30 am and 12:00 pm. In both coffee crops (shaded and sun systems), a total of 168 individuals were collected manually in that period.

This exploratory work offers an overview of the potential that weeds can offer in coffee crops as sources of food and shelter for the great diversity of natural enemies. These plants can play an important role in biological control by conservation. Therefore, it is necessary to further research their relationship with natural enemies, which are fundamental in regulating the populations of coffee phytophagous insects.

Conflict of interests: The authors declare that there is no conflict of interest.

\section{BIBLIOGRAPHIC REFERENCES}

Aldana, J.; Calvache, H.; Escobar, B.; Castro, H. (1997). Las plantas arvenses benéficas dentro de un programa de manejo integrado de Stenoma cecropia Meyrick, en palma de aceite. Palmas. 18 (1): 11-21.

Armbrecht, I.;Gallego, M. C. (2007). Testing ant predation on the coffee berry borer in shaded and sun coffee plantations in Colombia. Entomologia Experimentalis et Applicata. 124 (3): 261-267. doi:https://doi.org/10.1111/j.15707458.2007.00574.x

Angilletta, M.; Huey, R.; Frazier, M. (2010). Thermodynamic effects on organismal performance: Is hotter better?. Physiological and Biochemical Zoology. 83(2): 197-206. doi: https:// doi.org/10.1086/648567

Bagny, L.; Roudine, S.; Quintero, J. A.; Allinne, C.; Daout, D.; Mauxion, R.; Carval, D. (2019) Pest-regulating networks of the coffee berry borer (Hypothenemus hampei) in agroforestry systems. Crop Protection. 131. doi: https://doi.org/10.1016/j. cropro.2019.105036

Barp, E.; Soares, G.; Giani, E.; Rodrigues, D.; Moreira, G. (2010). Variation in Nectar and Pollen Availability, Sucrose Preference, and Daily Response in the 
Use of Flowers by Heliconius erato phyllis. Journal of Insect Behavior. 24: 200-219. doi: https://doi. org/10.1007/s10905-010-9248-2

Begg, G.; Cook, S.; Dye, R.; Ferrante, M.; Franck, P.; Lavigne, C.; Lovei, G.; Mansion-vaquie, A.; Pell, J.; Petit, S.; Quesada, N.; Ricci, B.; Wratten, S.; Birch, N. (2017). A functional overview of conservation biological control. Crop Protection. 97: 145-158. doi: https://doi.org/10.1016/j.cropro.2016.11.008

Bizumungu, G.; Majer, J.; Fay, H. (2019).The potential protective value of ants in Northern Australian coffee plantations. International Journal of Pest Management. 66(3): 227-238. doi: https://doi.org /10.1080/09670874.2019.1616129

Blanco, Y.; Leyva, A. (2013). Las arvenses y su entomofauna asociada en el cultivo del frijol (Phaseolus vulgaris, L.) posterior al periodo crítico de competencia. Avances en Investigación Agropecuaria. 17(3): 51-65. doi: https://www. redalyc.org/articulo.oa?id=83728497005

Borkhataria, R.; Collazo, J.; Groom, M. (2012). Species abundance and potential biological control services in shade vs. sun coffee in Puerto Rico. Agriculture, Ecosystems and Environment. 151: 1-5. doi: https:// doi.org/10.1016/j.agee.2012.01.025

Bray, J. R.,; Curtis, J. T. (1957). An ordination of the upland forest communities of southern. Ecological monographs. 27 (4): 325-349.

Brévault, T.; Clouvel, P. (2019). Pest management: Reconciling farming practices and natural regulations. Crop Protection. 115:1-6. doi: https:// doi.org/10.1016/j.cropro.2018.09.003

Bustillo, A. (2008) Historia sobre los artrópodos plagas en los cafetales de Colombia. En: Bustillo, A. Los insectos y su manejo en la caficultura. pp. 14-20. Colombia: Chinchiná. 92p.

Carles-Tolrá, H. M. C (2015). Orden Diptera. Revista IDE@-SEA. 63: 1-22.

Castro, A. M.; Tapias, J.; Ortiz, A.; Benavides, P.; Góngora, C. (2017). Identification of attractant and repellent plants to coffee berry borer, Hypothenemus hampei. Entomologia Experimentalis et Applicata. 164:120130. doi:https://doi.org/10.1111/eea.12604

Chen, Z.; Liu, L.; Liu, S.; Cheng, L.; Wang, X.; Xu, Y. (2017) Response of Chrysoperla nipponensis (Okamoto)
(Neuroptera: Chrysopidae) under long and short photoperiods. Journal of insect science. 17(2):1-9. doi: https://doi.org/10.1093/jisesa/iex005

De la Vega, M.; Lemir, A.; García, A.; Pace, R.; Aceñolaza, M. (2000) Control de Commelina erecta L. con herbicidas postemergentes con el objetivo de su uso en cultivos de soja transgénica. Planta Daninha. 18 (1): 51-56. doi: https://doi.org/10.1590/S010083582000000100005

Fernández, J.; Garcés, G.; Portuondo, E.; Valdés, P.; Expósito, I. (2001). Insectos asociados con flores de malezas del Jardín Botánico de Santiago de Cuba, con énfasis en Hymenoptera. Revista de Biología Tropical. 49 (3-4): 1013-1026.

Giraldo, M.; Galindo, L. A.; Benavides, P. (2011). La arañita roja del café biología y hábitos. Avances Técnicos Cenicafé. 403: 8.

Gómez, A.; Ramírez, C.J.; Cruz, R.G.; Rivera, J.H. (1987). Manejo y control integrado de malezas en cafetales y potreros de la zona cafetera. Chinchiná: FNC Cenicafé. $254 \mathrm{p}$.

Gómez, L.; Caballero, A.; Baldión, J. (1991). Ecotopos Cafeteros de Colombia. Bogotá: Cenicafé. 138p.

Instituto de Hidrología, Meteorología y Estudios Ambientales- IDEAM. (2021). Consulta y Descarga de Datos Hidrometeorológicos. Recovered from http://dhime.ideam.gov.co/atencionciudadano/

Jimenez-Soto, E.; Morris, J.; Letourneau, D.; Philpott, S. (2019). Vegetation connectivity increases ant activity and potential for ant- provided biocontrol services in a tropical agroforest. Biotropica. 51:112. doi: https://doi.org/10.1111/btp.12616

Le Pelley, R.H. (1973) Coffee insects. Annual Review of Entomology. 18:121-142.

Lundgren, J.G. (2009). Relationships of Natural Enemies and Non-prey Foods. First edition. The Netherlands: Springer International. 365p.

Mkenda, P.; Ndakidemi, P.; Stevenson, P.; Arnold, S.; Darbyshire, I.; Belmain, S.; Priebe, J.; Johnson, A.; Tumbo, J.; Gurr, G.(2020). Knowledge gaps among smallholder farmers hinder adoption of conservation biological control. Biocontrol Science and Technology. 30:1-22. doi: https://doi.org/10.1 080/09583157.2019.1707169

Morris, J.; Jiménez-Soto, E.; Philpott, S.; Perfecto, I. (2018). Ant-mediated (Hymenoptera: Formicidae) 
biological control of the coffee berry borer: Diversity, ecological complexity, and conservation biocontrol. Myrmecological News. 26:1-17.

Morris, J.; Perfecto, I. (2016). Testing the potential for ant predation of immature coffee berry borer (Hypothenemus hampei) life stages. Agriculture, Ecosystems and Environment. 233:224-228. doi: https://doi.org/10.1016/j.agee.2016.09.018

Peláez, O. E.; Santamaría, Y. (2010). Agenda Ambiental del Municipio de Ibagué. Primera edición. Ibagué: CORTOLIMA-Alcaldía Municipal de Ibagué. 189 p.

Perfecto, I.; Rice, R.; Greenberg, R.; Van der Voort, M. (1996). Shade Coffee: A Disappearing Refuge for Biodiversity. BioScience. 46 (8): 598-608. doi: https://doi.org/10.2307/1312989

Perfecto, I.; Vandermeer, J.; Mas, A.; Soto, L. (2005). Biodiversity, yield, and shade coffee certification. Ecological Economics. 54: 435-446.doi: https://doi. org/10.1016/j.ecolecon.2004.10.009

Rafael, J.; Melo, G.; De Carvalho, C.; Casari, S.; Constantino, R. (2012). Insetos do Brasil. Diversidade e Taxonomía. Brasil: Holos. 795p.

Ramírez, V.H.; Robledo, Á.; Peña, A. J. (2013). Gestión del riesgo agroclimático: Vulnerabilidad $y$ capacidad de adaptación del sistema de producción de café. En: Gast F, Benavides P, Rodrigo J, Herrera J, Ramírez V, Cristancho M, Marín S. (eds.). Manual del Cafetero Colombiano Investigación y tecnología para la sostenibilidad de la caficultura. pp. 91-114. FCN-Cenicafé. 326p.

Reith, M.; Zona, S. (2016) Nocturnal flowering and pollination of a rare Caribbean sage, Salvia arborescens (Lamiaceae). Neotropical Biodiversity. 2(1): 115-123. doi: https://doi.org/10.1080/2376 6808.2016.1230461

Rusch,A.;Bommarco, R.;Ekbom,B. (2016).Conservation Biological Control in Agricultural Landscapes. Agroecology and Crop Protection.81:1-28.doi: http://dx.doi.org/10.1016/bs.abr.2016.11.001

Sendoya-Corrales, C. A.; Bustillo-Pardey, A. E. (2016). Enemigos naturales de Stenoma cecropia (Lepidoptera: Elachistidae) en palma de aceite, en el suroccidente de Colombia. Revista Colombiana de Entomología. 42 (2): 146-154. doi: https://doi. org/10.25100/socolen.v42i2.6685
Silveira Neto, S., Nakano, O.; Barbin, D.; Villa Nova, N.A. (1976). Manual de ecologia dos insetos. Piracicaba: Ceres. 419p.

Southwood, T.R.E. (1995). Ecological methods with particular reference to the study of insect populations. London: Chapman and Hall. 524p.

Staver, C.; Juventia, S.; Navarrete, E.; Navarrete, L.; Sepulveda, N.; Barrios, M. (2020). Long-term response of groundcover components to organic and conventional weed control in shaded and open-sun coffee in Nicaragua. Crop Protection. 133: 1-12. doi: https://doi.org/10.1016/j.cropro.2020.105150

Triplehorn, C; Johnson, N. (2005). Borror and Delong's introduction to the study of insects. 7tha edition. USA: Thomson Brooks/Cole. 864p.

Vandermeer, J.; Perfecto, I.; Philpott, S. (2010). Ecological complexity and pest control in organic coffee production: Uncovering an autonomous ecosystem service. BioScience. 60 (7):527-537. doi: https://doi.org/10.1525/bio.2010.60.7.8

Van-Driesche, R; Hoddle, M; Center, T. (2008). Control of Pests and Weeds by Natural Enemies. An Introduction to Biological Control. First edition. Oxford: Blackwell Publishing. 502p.

Vargas, G.; Obando-Melo, V.; Gómez-Laverde, L. A. (2006). Jaynesleskia jaynesi: otra alternativa para el manejo de Diatraea sp. Carta Trimestral. Cenicaña. 28 (2): 3-5.

Vázquez, L.; Matienzo, Y.; Veitía, M.; Alfonso, J. (2008). Conservación y manejo de enemigos naturales de insectos fitófagos en los sistemas agrícolas de Cuba. Ciudad de La Habana: CIDISAV. 198.

Vélez, M.; Bustillo, Á.; Posada, F. (2006). Depredación de Hypothenemus hampei por hormigas, durante el secado solar del café. Cenicafé. 57(3):198-207.

Waller, J.M; Bigger, M; Hillocks, R.J. (2007). Coffee pests, Diseases and Their Management. First edition. Cambridge, MA: CAB International. 434p. 